\title{
Study of the Evaluation Framework of Management Quality of Primary and Secondary Schools Based on Resource-Based Theory
}

\author{
Shanmei Zhang \\ School of Government Administration, Beijing Normal University, Beijing, China \\ Email: shanmeizhang@163.com
}

How to cite this paper: Zhang, S. M. (2017). Study of the Evaluation Framework of Management Quality of Primary and Secondary Schools Based on Resource-Based Theory. Creative Education, 8, 893-900.

https://doi.org/10.4236/ce.2017.86064

Received: May 3, 2017

Accepted: May 22, 2017

Published: May 25, 2017

Copyright $\odot 2017$ by author and Scientific Research Publishing Inc. This work is licensed under the Creative Commons Attribution International License (CC BY 4.0).

http://creativecommons.org/licenses/by/4.0/

(c) (i) Open Access

\begin{abstract}
Effective school assessment is an important means in helping schools find problems, analyze problems and solve problems. However in the background of increasing demand of "good schools", how to further improve the quality of running a school by assessing has become the main challenge for many headmasters and the relevant scholars. Especially when the educational government will be separated from schools, it is difficult for primary and secondary schools to be clear about the direction and focus of self-management as lack of the basic theory, basic ideas and practical experience of self-management. As a result, primary and secondary schools need a kind of self-managementoriented evaluation system which can guide them to do the right thing in the very beginning of self-management period to improve the quality of schools' running. Based on a lot of literature analysis and practice research, this paper tries to construct a school management evaluation framework based on resource-based theory to help schools step into the right way.
\end{abstract}

\section{Keywords}

Resource-Based Theory, School Management, Strategic Resource, Evaluation Framework

\section{Introduction}

With the development of the society and the change of educational philosophy, more and more Chinese want their children to study in schools with higher quality both in teaching and management which will help their children grow up better but not in general schools. So how to improve the quality is becoming a new challenge for many primary and secondary schools especially in the background of school's self-development which means the those schools will be se- 
parated from the educational administration units in the area of school management. In other words, primary and secondary schools in China can't depend on the educational administration units as before but can only depend on themselves to find out the development ways. This paper tries to help those schools to improve their quality from the perspective of building a more effective evaluation framework that will be based on the idea of self-management and endogenous development.

\section{Method}

\subsection{Elaborate the Applicability of Resource-Based Theory in the Area of School Management Evaluation}

Resource-Based Theory (RBT) is a strategic management theory by Barney, Rumelt, Peteraf and other scholars on how to use the organization's internal resources to gain a competitive advantage (Ma, 2001). Barney and other RBT researchers believe that with the acceleration of the enterprises' external changes, the external environment will be more difficult to be predicted and analyzed. So the enterprise should pay more attention on their internal resources to build their competitive advantage by but not external environment (Wegloop, 1995).

School management includes many staff but the general conception of school management is the school administrators design, co-ordinate and organize activities to achieve a certain or a few goals based on the core school resources for improving education quality. What's more, with the guidance of the idea of school endogenous development, school administrators will have to focus on their internal resources more with less and less external favor.

With the completion of the "two basics" project ${ }^{1}$ across the country, China has basically solved the problem of quantity of schools in the perspective of the total school's number and the quantity of schools' hardware to support the common teaching affairs (Feng, 2012). Especially in economically developed areas in China, many primary and secondary schools already have the basis of the endogenous development which calls schools to use their own resources to improve the quality of a school and build the school's own characteristic.

Actually, in order to improve quality and build characteristic, schools must depend on internal resources. On one hand, to build the characteristics of a school which means the school has a unique competitive advantage in one area, must rely on school internal resources (Ren, 2010), because it is inevitable to be restricted by the external environment when depending on external resources. Depending on external resources will restrain the initiative and creativity of the school teachers and students and will finally lead schools to homogeneous ones (Zheng, 2007). But based on RBT, once the school focused on their own internal resources, they will have the endogenous motivation to explore, to change and to build their own characteristics. On the other hand, to improve quality which means training more outstanding teachers and more excellent students, schools

${ }^{1}$ Two-Basic Project: Basically popularize nine-year compulsory education and Basically eliminate the young illiteracy. 
should pay more attention to the comprehensive development by relying on the internal resources. As the key to the overall level of school education is the core internal resources directly related to "human development" like high-quality human resources, rich and shared knowledge resources and the most profound cultural resources.

So, the school management model based on RBT is not just in line with the requirements of the idea of school endogenous development but also a necessary choice for schools to enhance their inherent quality. As a conclusion, it is reasonable and scientific to manage a school and build a school management evaluation system based on RBT.

\subsection{Analyze the Status Quo of Primary and Secondary School Management Evaluation in China}

From the 1980s, studies on primary and secondary schools' evaluation are keeping increasing. Among them, the evaluation of school management is also increasing. However, due to the huge differences of education level in China, schools in different regions are in different assessment stage. For example, some schools are in the budding period. They just have an ambiguous cognition of "school management" and there is no formal "school management" dimension. In the school assessment system, some schools are in the normative management-oriented period. They already have a clear cognition of "school management" and even build the "school management" dimension in the assessment system. But the focus of the assessment is just the regular management activities. For example, although the "2011 Pudong New Area compulsory education school performance appraisal approach" includes the "school management" dimension, the school management here just points to financial management, human resources publicity, infrastructure management but no other core management activities like knowledge resource management, cultural resource management (Shanghai Pudong New Area Education Bureau, 2011). Besides, there are still some fast-growing schools which had already entered the endogenous development period. At this stage, school management assessment began to focus on the school's developmental indicators and make the development the new orientation. For example, "school management" of the "2014 Shandong Province compulsory education stage provincial standardization school assessment standards" is built to improve management efficiency including 7 parts like setting up the school concept and development planning, management system, management team building, teacher's training, school-running behavior, campus culture construction, safety and regular management (Zhao, 2013).

Although the assessments of school management in primary and secondary schools have differences in different regions, the importance of school management has reached a consensus: school management is becoming an important part of the comprehensive evaluation system of school running. However, there is an obvious shortcoming in the current school management assessment that most of the schools which have already completed the infrastructure construc- 
tion are still using a regular management oriented assessment systems whose indicators often failed in reflecting the school's strategic development factors but just some regulate daily management factors. In the background of school endogenous development, more and more primary and secondary schools will face to the challenges from school management, like management philosophy, management method, management process and so on. In dealing with those challenges, the most effective measure is to change the mode of resource dependence from depending on the external resources to get larger school scale to depending on the internal resources to improve the essentially education quality.

Therefore, this study argues that it is necessary to establish a new primary and secondary school management evaluation system with the core of the strategic resources to guide the primary and secondary school administrators to step to the right way of school endogenous development.

\subsection{Construct the Evaluation Framework of School Management from the Perspective of Resource Management}

In accordance with its importance, resources in primary and secondary school can be divided into basic resources and strategic resources. The strategic resources are resources that have the decisive role in promoting the quality of school development. Based on the idea of "endogenous development", a school should achieve the goal of having excellent teachers and outstanding students, being high-level and special (Cheng, 2013). Therefore the strategic resources should be the ones that can direct help achieve the goal such as the human resources, the knowledge resources, the culture resources. On the contrast, resources like site facilities, teaching equipment and other material resources are almost all provided by the local government or social support and can help a school when it's in the stage of start-up period but not that pivotal when a school is stepping into the road of endogenous development.

Human resources are the core strategic resources of school management. School's human resources refer to the general category of people with intellectual ability and physical ability who are in labor and can promote the development of school through professional training (Wang, 2011). And those people are usually divided into two kinds: teaching staff and administrative staff both essential for the development of a school. On one hand, the teacher team is the most important factor that affects the students' academic progress and physiological growth (Zhang, Bian, \& Wang, 2012). On the other hand, the level of the school management team decides the goal and development of a school (Cheng, 2013). Actually any development and change of a school are inseparable from the high quality of human resources. Especially when most schools don't know how to improve the enthusiasm, initiative and creativity of teachers and other administrator, high-quality school talent team is very scarce which means human resources need to be developed badly. Human resources development and management of a school points to the whole process of planning, recruiting, training, using, evaluating and encouraging the teaching staff and management 
staff and keeping developing their ability and quality to achieve the goal of school (Liu, 2009). The general human resources in the education system include both the teachers and the management team. Therefore, in the design of the third indicators, the human resources are firstly divided into two categories: management personnel and teaching talents. After that, sum up the key factors that will influent the development of human resources. For the teaching talents, we find out the key factors according to their growth path including being guided to be professional and growing better in the influence of the external environment. The key indicators of guidance refer to the professional career guidance and training. The key indicators of the external environment refer to the incentive system and campus cultural atmosphere. For the management team, we first treat them as general talents to assess the basic conditions of their development such as the rationality of organizational structure, the clarity of the functional positioning of the department and the responsibilities of various departments. On the other hand, management talents must have service awareness and ability to be professional administrators.

Knowledge resources are the most basic strategic resources of school management. In school, study on the development and utilization of knowledge resources has lasted for a long time and even create the concept of "knowledge management" to describe the process of creating, sharing and using knowledge. The strategic significance of knowledge resources lies in its role in promoting the quality of school's human resources, because the school's talent team must have sufficient knowledge resources to become more professional (Mao, 2003). In addition, when a school wants to break through the bottleneck, they must rely on knowledge resources sharing to inspire people to exchange their experience and inspiration and create together the more effective ways to run the school. So from the perspective of promoting the value of human resources and the perspective of building the school's innovative atmosphere, knowledge resources are basic to provide the most fundamental guarantee of strategic resources. Knowledge management means school administrators use various knowledge to enhance process of creating value (Alavi, Leidner, \& Zheng, 2012). Generally, knowledge can be divided into explicit knowledge and tacit knowledge. Explicit knowledge that have been encoded may disappear as lack of platform construction, technical support (Ma, Gao, \& Jiang, 2007). Meanwhile, tacit knowledge which is difficult to understand and imitate because of not encoded could disappear for people don't want to share this kind of knowledge as there's no relevant incentive conditions to inspire them to do so. Therefore, this study build the level 3 dimensions based on the whole process of knowledge management from knowledge innovation, knowledge acquisition, knowledge sharing and knowledge storage.

Cultural resources are the most characteristic strategic resources of school management. The cultural resources of the school are based on the recognition of all members with the external phenomenon, campus atmosphere and behavior of all the members. Culture is an important characteristic of a school dif- 
ferent from other schools. School culture can not only regulate and guide the behavior of teachers and students but also improve the school's management standard. It can be said that without suitable culture, it will be difficult for a school to achieve sustainable and high-quality development (Ren, 2010). So if a school wants to create characteristics of themselves, the development of cultural resources is undoubtedly the best way. School culture can be divided into 3 kinds like material culture, institutional culture and spiritual culture. However because the material culture involves too many financial investment outside, we can't take it as the inside resources. But institutional culture and spiritual culture are very important to school management. Because institutional culture is the protection of school culture with creating many rules and regulations in various organizations of a school to guide the school staffs do the right thing in the suitable circle. And spiritual culture is the core of the school culture which will ultimately affect the behavior of all school staff and make the school independent and develop characteristic (Fu, 2006). In addition to the system culture, spiritual culture, the study also makes the curriculum culture as a very important indicator because the curriculum is the main carrier of all kinds of school culture ((Chen, $\& \mathrm{Li}, 2010)$.

After determining the three core strategic resources for the school's endogenous development, school administrators need to adopt appropriate models and methods to plan, integrate, develop and utilize the above strategic resources. In order to ensure the effectiveness of resource integration, school administrators must make a plan to use those various strategic resources uniformly and orderly. Then how to make resource management work? How to judge the level of a school's management of strategic resource? This requires building a resource based assessment system including four aspects: human resource management, knowledge resource management, cultural resources and strategic planning. Strategic planning is a series of activities closed-loop management process including implementation, monitoring, evaluation, feedback and adjustment. Compared with other management activities, strategic planning has a very clear time node. So according to the principle of key events, this study selects core factors of every activity. In the implementation phase of the school strategic planning, the key work mainly includes the implementation of the strategic planning text, how to control and adjust the existing work. The assessment of school strategy planning includes whether the assessment is effective and whether the assessment is reasonable. Finally, we will evaluate whether the school strategic planning bring great results according to the satisfaction survey, mainly from the development of students, external evaluation to measure the internal and external "customer" satisfaction.

\section{Conclusion}

After the above analysis, we finally get the evaluation framework of school management with the guidance of resource-based theory. The evaluation framework is constituted by four level 2 dimensions and eighteen level 3 dimensions. 
The four level 2 dimensions include human resource management, knowledge resource management, cultural resources management and strategic planning management. The human resource management includes five level 3 dimensions: organization of management team, career literacy of management team, performance of management team, training to teaching team, leading and excitation to teaching team. The knowledge resource management includes four level 3 dimensions: knowledge innovation, knowledge acquisition, knowledge sharing and knowledge storage. The cultural resource management includes four level 3 dimensions: institutional culture, behavior culture, curriculum culture and result of culture resource management. The strategic planning management includes five level 3 dimensions: formulation of strategy planning, execution of strategy planning, assessment of strategy planning, improvement of strategy planning, and result of strategy planning.

\section{References}

Alavi, M., Leidner, D. E., \& Zheng, W. Q. (2012). Knowledge Management and Knowledge Management System: Conceptual Foundation and Research Topic. Management of the World, 5, 157-169.

Chen, S. S., \& Li, J. J. (2010). Curriculum Culture: The Core of School Culture Construction. Educational Development Research, 3, 8-11.

Cheng, X. G. (2013). Happiness Longing: The School Connotation of the Development of Thinking and Practice. Beijing: Beijing Normal University Press.

Feng, J. J. (2012). Connotation Development: The Way to Promote the Quality of Compulsory Education Balanced Choice (pp. 119-125). Nanjing: Nanjing Social Sciences.

Fu, Y. (2006). Briefly on the School Culture. Modern Primary and Secondary Education, 4, 4-6.

Liu, J. (2009). Study on the Development and Management of Human Resources in Elementary Education Schools_Taking Shanghai $※ *$ District as an Example. Shanghai: Fudan University.

Ma, W. W., Gao, Y., \& Jiang, L. (2007). Imagination and Balance: The Starting Point and Destination of School Knowledge Management. Educational Development Research, $10,59-62$.

Ma, Y. (2001). Study and Reflection on the Basic Theory of Resources. Economics and Management, 12, 23-27.

Mao, Y.-Q. (2003). Innovation of Knowledge Management and School Management. Educational Research, 6, 55-60.

Ren, S. Y. (2010). School Characteristics and Characteristics of School Construction. Hangzhou: Zhejiang University Press.

Shanghai Pudong New Area Education Bureau (2011). Pudong New Area Education Bureau on the 2011 Compulsory Education School Performance Appraisal Work Implementation Opinion.

Wang, J. (2011). Study on Human Resource Management and Innovation in Colleges and Universities. Journal of Shanxi University of Finance and Economics, S3, 248-249.

Wegloop, P. (1995). Firm Strategy and Government Action: Toward a Resources-Based perspective on Innovation and Technology Policy. Technology in Society, 17, 413-428. https://doi.org/10.1016/0160-791X(95)00017-L 
Zhang, Q. R., Bian, Y. F., \& Wang, Y. H. (2012). The Influence of School Education Environment and Resources on Adolescent Academic Achievement. Educational Research, $8,32-40$.

Zhao, C. X. (2013). Research on the Evaluation Index of Junior Middle School Education. Beijing: Higher Education Press.

Zheng, J. Z. (2007). Connotation of School Development: Implication and Implementation. Educational Science Research, 10, 23-28.

Submit or recommend next manuscript to SCIRP and we will provide best service for you:

Accepting pre-submission inquiries through Email, Facebook, LinkedIn, Twitter, etc. A wide selection of journals (inclusive of 9 subjects, more than 200 journals)

Providing 24-hour high-quality service

User-friendly online submission system

Fair and swift peer-review system

Efficient typesetting and proofreading procedure

Display of the result of downloads and visits, as well as the number of cited articles Maximum dissemination of your research work

Submit your manuscript at: http://papersubmission.scirp.org/

Or contact ce@scirp.org 